\title{
The Relationship Of Family And Teacher Support By Self Retardation In Children Mental School Of Plambuan
}

\author{
Dwi Sogi Sri $\mathrm{R}^{1 *}$ \\ ${ }^{1}$ Sari Mulia School of Health Science, Banjarmasin \\ *rr.dwi_sogi_sriredjeki@stikessarimulia.ac.id \\ Hendy Agus $\mathrm{R}^{1}$ \\ ${ }^{1}$ Sari Mulia School of Health Science, Banjarmasin \\ hendy_agus@stikessarimulia.ac.id \\ Anggrita Sari $^{2}$ \\ ${ }^{2}$ Midwifery academy Sari Mulia School, Banjarmasin \\ anggrita_sari@akbidsarimulia.ac.id \\ Rizqy Amelia ${ }^{2}$ \\ ${ }^{2}$ Midwifery academy Sari Mulia School, Banjarmasin \\ rizqy_amelia@akbidsarimulia.ac.id \\ Istifadah $^{1}$ \\ ${ }^{1}$ Sari Mulia School of Health Science, Banjarmasin \\ istifadah@gmail.com
}

\begin{abstract}
Objective: Based on the result of discussions with 5 families of children with mental retardation in December 2016 that the family experience to train the independence of children with mental retardation is different. Family teaches his son to be able to do shower activities, oral hygiene, dressed neatly, and doing toilet training, defecate, urinate, well and correctly, however the cleanliness of the bath, oral hygiene, and toileting in children is still lacking, total of 8 families with mentally retardation children said that for girls who have menstruation are usually still assisted by their mother or grandmother, but girls toileting is quicker to understand and tends to be more independent.

Method: The type of research used correlation with cross-sectional approach. The population o the whole family who had mentally retarded children as many as 124 pupils in elementary school retarded pelambuan and teachers as many as 8 people in elementary school. The sample in this study using the method of sampling amounted to 55 people. Data were collected using questionnaire analyzed by spearman rank correlation test $(\alpha=0,05)$.

Results: The result showed that the parents in retarded elementary school Banjarmasin with the classification did not support amounted to 31 people $(56,4 \%)$, teachers in retarded elementary school Banjarmasin which supports the independence of students, nonindependent children amounted to 30 people $(54,5 \%)$.

Conclusion: There is a relationship of teacher support with independence in children retardation elementary school Pelambuan Banjarmasin.
\end{abstract}

Keywords: Family support, teacher support, independence, child retardation 


\section{INTRODUCTION}

Independence in children with mental retardation is necessary. Independence is good in terms of child's daily activity, personal hygiene or daily life issues. Children with mental retardation have different limitations depending on the deficiencies they have [1]

Persons with moderate mental retardation who have not been able to perform daily activities or self-reliance in self-care not merely because of useful but because the environment is less supportive, it takes a guidance, both from the family or community, which is expected to have mental retardation have ability in self-care, if the ability is really mastered it will provide confidence in people with mental retardation is being. The role of the family to improve self-care abilities in children mental retardation can be by facilitating, providing motivation or support [2]. Said family support is the attitude, action, and acceptance of the family of the sick. Families have several support functions including emotional support, self-esteem, instrumental, informational and social groups [3].

Preliminary study results conducted on 02 to 06 December 2016 note that Retarded elementary school Pelambuan
Banjarmasin has received children who have mental retardation from 1982 to 2016 as many as 1.227 children and since 2004 . began to be established a retarded junior high school.

In 2016, the number of retarded elementary school students Pelambuan Banjarmasin as many as 153 people with the division of students up at Retarded school as many as 24 people and retarded elementary school as many as 129 people. The age range of students of mental retardation starts from the age of 6 to 25 years.

The classification of mental retardation in elementary school Pelambuan was 61 children had mild mental retardation, 52 children had mild mental retardation.and 16 children had severe mental retardation. While at retarded junior high school, 18 children had mild mental retardation, 5 were mentally retarded and one had severe mental retardation.

Based on the results of discussions with 5 families of children with mental retardation on December 6, 2016, that the family experience to train the independence of children with mental retardation is different. The family teaches their children to perform shower activities, oral hygiene (brushing teeth), dressed up neatly, and doing toilet training; Defecate and Urinate 
properly and correctly. [4] However, the cleanliness of bathing, oral hygiene, and toileting in children is still lacking. As many as 8 families who have children mentally retarded women say that for girls who experience menstruation are usually still assisted by their mother or grandmother, but toileting girls' affairs more quickly understand and tend to be more independent [5]. The results of the discussion provide full child support, this can be seen from the achievements that have been children and schools achieve such as the 2nd champion Scratch Animation, champion II Scratch Game, retarded school No. 1. I Level of Provinces, General Champion of National Creativity, 2nd Winner of Siona Province of South Kalimantan Region and many other awards, while some families admitted to not supporting their children with achievement due to family worries, less cost, less information and families who resigned and ignored, while some teachers say tired to guide students with mental retardation because they have to try various ways so that their students will follow the competence while some teachers say less interested in terms of supporting student independence [6].

This study aims for the relationship of family and teacher support with independence in children mental retardation in school Pelambuan Banjarmasin.

\section{METHOD}

This research uses the descriptiveanalytic method with cross-sectional approach. The population of the case is the whole family who has children mental retardation as many as 124 people in retarded school Pelambuan and teachers as many as 8 people in retarded elementary school Pelambuan Banjarmasin. The sample in this study using the method of sampling is as many as 55 families who have children mental retardation and teacher samples in this pedestrian of 8 teachers at retarded elementary school Pelambuan Banjarmasin. Data collection using questionnaire analyzed by Spearman rank correlation test $(\alpha=0,05)$.

\section{RESULTS}

a. Family support for children with mental retardation in retarded school Pelambuan Banjarmasin can be seen in the table

Table 1 Frequency distribution of family support in child mental retardation at Retardation School Pelambuan Banjarmasin

\begin{tabular}{lll}
\hline Family support & f & $\%$ \\
\hline Support & 31 & 56,4 \\
Not support & 24 & 43,6 \\
\hline Total & 55 & 100 \\
\hline
\end{tabular}

The results showed that the parents in retarded school Pelambuan Banjarmasin with the classification did not support 
amounted to 31 people $(56.4 \%)$ and the parents with the classification of support amounted to 24 people $(43.6 \%)$.

b. Support teacher in retarded school pelambuan Banjarmasin

Support of teachers in children mental retardation in school Pelambuan Banjarmasin can be seen in table 2:

Table 2. Distribution Frequency of Teacher support to children mental retardation at school Pelambuan Banjarmasin

\begin{tabular}{lll}
\hline Support teacher & f & $\%$ \\
\hline Not support & 2 & $25 \%$ \\
Support & 6 & $75 \%$ \\
\hline Total & 8 & 100 \\
\hline
\end{tabular}

The results showed that teachers in retarded school Pelambuan Banjarmasin with classification support amounted to 6 people $(75 \%)$ and teachers with no support classification amounted to 2 people $(25 \%)$. The results showed that teachers in retarded school Pelambuan Banjarmasin that support student independence. This can be seen in the way of teachers who always appreciate the actions of the students as well as give students the motivation and support to be independent in doing anything.

c. Child independence in the retarded school of pelambuan Banjarmasin in table 3:

Table 3 Frequency Distribution of Child Independence

\begin{tabular}{lll}
\hline Independence child & $\mathrm{f}$ & $\%$ \\
\hline Not independence & 30 & 54,5 \\
Independence & 25 & 45,5 \\
\hline Total & 55 & 100 \\
\hline
\end{tabular}

The results showed that there were 30 independent students (54.5\%) and independent children (25.5\%).

2. Bivariate analysis

Relationship of Family Support with Independence in Child Mental Retardation in school Pelambuan Banjarmasin

The results of research conducted on the relationship of family support with independence in children mental retardation in School Pelambuan Banjarmasin can be seen in table 4

Table 4 Relationship of Family Support with Independence in Child Mental Retardation in School Pelambuan Banjarmasin

\begin{tabular}{lllllll}
\hline & \multicolumn{4}{l}{ Independent } & & \\
\cline { 2 - 6 } Family support & \multicolumn{2}{l}{$\begin{array}{l}\text { Not } \\
\text { independent }\end{array}$} & \multicolumn{2}{l}{ Independent } & \\
\cline { 2 - 6 } & $\mathrm{F}$ & $\%$ & $\mathrm{f}$ & $\%$ & $\mathrm{f}$ & $\%$ \\
\hline Not support & 26 & 83,9 & 5 & 16,1 & 31 & 100 \\
Support & 4 & 16,7 & 20 & 83,3 & 24 & 100 \\
\hline Total & 30 & 54,5 & 25 & 45,5 & 55 & 100 \\
\hline $\mathrm{p}=0,000(<\alpha=0,05)$ & & & & & &
\end{tabular}

The result of research from 55 parents in retarded school Pelambuan Banjarmasin known that parents do not support with children who are not independent amounted to 26 people $(83,9 \%)$.

The result of analysis with rank's Spearman correlation test showed that $\mathrm{p}=$ $0,000(<\alpha=0,05)$ or it can be said that there is a significant correlation between family support and independence in child mental 
retardation at School Pelambuan Banjarmasin.

The correlation value of 0,669 means that both variables have a perfect linear relationship (positive straight line). Such perfect correlations have meaning if the value of family support rises, then the child's independence also rises. Correlation coefficient value 0,669 included in category> 0,5-0,75 which mean relation of family support with independence in a child of mental retardation at school Pelambuan Banjarmasin enters in strong category.

Relationship of Teacher Support with Independence in Children Mental Retardation in school Pelambuan Banjarmasin The results of the research by means of question and answer to show that the support of teachers is very related to the independence of children. This is because teachers provide education or science of children in school so that children know the good and things that are not good to do.

\section{DISCUSSION}

Based on the results of research that has been done in school Pelambuan Banjarmasin about the relationship of family and teacher support with independence in children mental retardation in School Pelambuan Banjarmasin.
The results showed that the parents in retarded school Pelambuan Banjarmasin with the classification did not support amounted to 31 people $(56,4 \%)$ and the parents with the classification of support amounted to 24 people $(43,6 \%)$. Most families with children with mental retardation are caused by feelings of shame and inferiority because their children have abnormalities and limitations compared with normal children in general. Parents and families who do not support the independence of their children due to fear or worry about something that can endanger their children. Parents who have more mental retardation children hide the child's identity and engage children to play and socialize with the environment and peers. Parents feel embarrassed and keep their child's feelings in order not to be humiliated by others that can result in their child's mental getting disturbed and depressed. Based on the results of the questionnaire is known that parents forbid children to continue to socialize but often invite children to walk or picnic.

Family social support is the attitude, action, and acceptance of the family of the sick. The family has several support functions including informational support, awareness, emotional and instrumental. 
Family social support is a beneficial condition for an individual acquired from others who can be trusted so that one will know that there are others who care about, appreciate and love.

The fact that the result of this research is found that there are 31 people $(56,4 \%)$ of parents in retarded school Pelambuan Banjarmasin with classification not support and parent with classification support 24 people $(43,6 \%)$ while 4 people $(7,3 \%)$ teachers in retarded school Pelambuan Banjarmasin that support and not support. This may be influenced by factors that affect the social support of the family such as education. According to [5] there are several factors that influence the parental social support of parenthood, father's involvement, parental education, previous experience in parenting and parental stress.

The results showed that teachers in SLB Pelambuan Banjarmasin with classification support amounted to 6 people $(75 \%)$ and teachers with no support classification amounted to 2 people (25\%). Teachers at retarded school Pelambuan Banjarmasin that support student independence. This can be seen in the way of teachers who always appreciate the actions of the students as well as give students the motivation and support to be independent in doing anything. Based on the results of the questionnaire it is known that the teacher always helps the students problem and always gives the students the spirit to keep school.

The family's social support and the teacher in the child's mental retardation greatly influences the attitudes and behavior of the child, especially in the mentally retarded child who needs special attention from the surroundings as well as one of the most important factors for the growth as well as the development of the child's mental retardation. With the support of the family and used as a daily so that the child can do something to realize a goal that after being supported by the family.

The results showed that there were 30 independent students (54,5\%) and independent children $(25,5 \%)$. Based on the results of research by Widyartanty (2009) with the title "the relationship of family motivation on the ability of self-care in children tunagrahita in retarded school Putra Jaya Malang" obtained the result that the majority of children tunagrahita at school age able to do self-care.

In children with mild mental retardation they have IQ 52-69 which means they are still able to educate means other than can be taught to read and write even to 
grade 4-6 SD, can also be trained in certain skills as the provision of his life later and able to be independent as a normal adult. The category of mental retardation is having IQ 36-51 which means they are still able to be trained to have self-care abilities, whereas in severe and very severe mental retardation children have difficulty in taking care of themselves because of a striking motor disorder or other deficits that accompany it and have intelligence that limited so difficult for the child to be taught how to care for himself.

The results showed that children who are not independent 30 people $(54,5 \%)$ and children are independent 25 people $(45,5 \%)$. Most children are not independent of parents and families who are highly overprotective of all child actions and behaviors. Parents are always watching and often children to do things themselves without being accompanied. In addition to the high sense of worry, parents consider this reasonable because it assumes the child who has different thoughts and it merpakan form of affection from parents to their children. With a long-edited questionnaire /shoe to be supported by children from their own cups in defecated and urinate.

Self-care is a behavior that individual or guardian exercises or works personally to maintain a healthy life and well-being. Self-care is strongly influenced by family experience in problem-solving, family education, culture, knowledge, growth, and parenting.

Persons with moderate mental retardation who have not been able to perform daily activities or self-reliance in self-care not merely because of keunaanya but because the environment is less supportive, it takes a guidance, both from the family or community, which is expected to have mental retardation have ability in self-care, if the ability is really mastered it will provide confidence in people with mental retardation is being. The role of the family to improve self-care abilities in children mental retardation can be by facilitating, providing motivation or support.

The result of research from 55 parents in retarded school Pelambuan Banjarmasin known that parents do not support with children who are not independent amounted to 26 people $(83,9 \%)$. The result of analysis with Spearman rank correlation test obtained that $\mathrm{p}=0,000(<\alpha=0,05)$ or it can be said that there is a significant relationship between family support with independence in children mental retardation in school Pelambuan Banjarmasin. 
Self-care is one of the basic human capabilities in fulfilling its needs to maintain its life, health, and well-being in accordance with its health condition, the client expressed disturbed keperwatannya if unable to perform self-care. The ability to care for oneself will lead the child's mental retardation to adjust to the environment and achieve independence. In doing self-care for children mental retardation is still in trouble, so they need to be taught and need a long time, more practice and help and repetitive teaching.

The result of analysis with Spearman rank correlation test obtained that $\mathrm{p}=0,000$ $(<\alpha=0,05)$ or it can be said that there is a significant relationship between family support with independence in children mental retardation in school Pelambuan Banjarmasin. The correlation value of 0.669 means that both variables have a perfect linear relationship (positive straight line). Such perfect correlations have meaning if the value of family support rises, then the child's independence also rises. Correlation coefficient value 0,669 included in category> 0,5-0,75 which mean relation of family support with independence in a child of mental retardation at school Pelambuan Banjarmasin enters in strong category.
It can be said that between family support to the ability of self-care in children mental retardation in school Pelambuan Banjarmasin has a positive relationship which means the better the family's social support to children mental retardation than the better the child's mental retardation in self-care.

This result is similar to research conducted by [6] entitled "The Relationship Between Social Support of Families With Socialization Capability of Mental Retardation Children" which obtained the result that there is a significant relationship between family support with the ability of socialization of children with grade 1 mental retardation in school Sukoharjo Pati. This relationship is a positive relationship, which means if family support is better then the socialization of children mental retardation will also be better and also research conducted [5] with the title "the relationship of motivation of the family to the ability of self-care in children tunagrahita in retarded school Putra Jaya Malang "which obtained the result that the higher the motivation of the family given to the child's child's tunagrahita the better the child's tunagrahita in doing self-care [7]. 


\section{CONCLUSION}

The results show that teacher support is strongly related to children's independence. This is because teachers provide education or science of children in school so that children know the good and things that are not good to do. Child mental retardation, especially mental retardation is in need of training and guidance to be able to perform activities independently. Training and guidance are not only from formal education but also informal education conducted by the family. a family is a group of people who have blood relations and will support each other. Families are the closest people who can have a positive impact on other family members.

\section{REFERENCES}

[1] DHS (2001a), Family Support Services: Enhanced Support for Families, Community Care Division, Victorian Government Department of Human Services, Melbourne.

[2] Gallagher, S., Phillips, A.C., Oliver, C., and Carroll, D., 2008. Predictors of Psychological morbidity in parents of children with Intellectual Disabilities. Journal of Pediatric Psychology 33 (10), 1129-1136.

[3] Weiss, M.J., 2002. Hardiness and social support as predictors of stress in mothers of typical children, children with autism, and children with mental retardation. Autism 6, 115-130.

[4] Khamis, V., 2007. Psychological distress among parents of children with mental retardation in the United Arab Emirates. Social Science and Medicine 64, 850857.

[5] Brandley, V.J. (2000). Changes in Services and supports for people with developmental disabilities: new challenges to established practice. Health and social work, 25, 3. 191-200

[6] Friedman, Marilyn. 2012. Keperawatan Keluarga: Teori dan Praktik, trans, Deborah, Asy, H. EGC. Jakarta.

[7] Stuart. Gail. W. 2010. Buku Saku Keperawatan Jiwa. Edisi ke 3. Jakarta: EGC. 